Advanced Research in
$\frac{\text { Gastroenterology \& Hepatology }}{\text { ISSN: 2472-6400 }}$
$\begin{aligned} & \text { Mini Review } \\ & \text { Dolume 12 Issue 3- February } 2019\end{aligned}$ Adv Res Gastroentero Hepatol
Col:19080/ARGH.2019.12.555838

\title{
Prevalence of HCV in Pakistani Population
}

\author{
Ghazala Rubi ${ }^{1 *}$ and Sahr Malik ${ }^{2}$ \\ ${ }^{1}$ Department of Genetics \& Molecular Biology, Post Graduate Medical Institute Lahore, Pakistan \\ ${ }^{2}$ Department of Molecular Biology, Lahore General Hospital, Pakistan
}

Submission: December 01, 2018; Published: February 13, 2019

"Corresponding author: Ghazala Rubi, Human Genetics \& Molecular Biology, Director Central Research Lab, Post Graduate Medical Institute Lahore, Lahore General Hospital, Lahore, Pakistan

\begin{abstract}
The high prevalence of $\mathrm{HCV}$, in Pakistan, is because of several factors some of which influence the occurrence rate of Hepatitis C in the short run while the other factors affect the occurrence rate in the long-run. The use of contaminated syringes, blood transfusion, and employment of unsterilized medical equipment during the medical process are the primary causes that influence the prevalence of HCV in short run while the socio-economic conditions, which affect the access to information and healthcare services affect the prevalence of HCV in long run, Rubi G et al. [1]. The prevalence of HCV varies from city to city and from province to province, which suggests that topographical factors also influence its occurrence rate. As per the statistical estimations, around 7\% of total population of Pakistan affected by HCV, while the large section of society is on the risk of exposure.
\end{abstract}

Keywords: HCV; Hepatitis C; Contaminated syringes; Blood transfusion; Unsterilized medical; Diseases; Chronic liver disease; Blood-borne virus; Healthcare units; Medical complications

\section{Introduction}

Hepatitis $\mathrm{C}$ is a chronic liver disease, which is caused by Hepatitis C virus (HCV). It is a liver disease that has a method of affecting a healthy body Kish \& Aziz et al. [2]. For instance, the virus initially damages the liver, which produces very few or no symptoms. As the early symptoms of the infectious disease are very mild and few; therefore, it remains undetected for a very long period Kitiyakara \& Redmond et al. [3].

In developing countries, where the awareness regarding the diseases is less and the medical methods to address Hepatitis C cases are less matured, the Riaz \& Latif et al. [4] infectious disease has not only a greater prevalence but also the recovery rate of Hepatitis C patients is also dismal Graham \& Swan [5].

As per the WHO statistics, the deaths caused by the bloodborne virus (Hepatitis C), are around 400, 000 per year and around 71 million people (worldwide) are presumed to have been infected by the chronic disease. Some recent studies, on this chronic infection, have inferred that the lack of a potent vaccine is the primary cause of the prevalence of this infectious disease at the biblical scale WHO [6]. (Note: Statistics show that the individuals, who are victim of this infectious disease, can be cured with the antiviral medicines. The chances of the recovery, of a person who is infected by Hepatitis $\mathrm{C}$ virus, are around 95 \%.) Prevalence of HCV in Pakistani Population
In Pakistan, a developing country where the disease has high occurrence rate, the major cause of the transmission of the Hepatitis C disease is blood transfusion, un-sterilized surgical instruments and unsafe injections Kumar et al. [7]. Several reports have found that in the healthcare sector of Pakistan, the use of already used syringe is quite common, especially in the rural areas of the country, where there is an absence of an effective system to monitor the medical activities, processes and procedures Qureshi \& Mohamud et al. [8]. The government, of Pakistan, has taken range of measures to ensure that the used syringe is not employed twice for the medical purposes (to inject a vaccine or to draw blood from the patient. However, these new policies or set of instructions are difficult to enforce at the macro scale, as the state does not have enough resources to ensure whether all the healthcare units, which are operating in urban or rural areas of the country, are implementing the new policy/ instruction or not WHO [6].

As per the most recent studies, around $7.5 \%$ of the total population of Pakistan is infected by Hepatitis C virus. However, the major concern for the healthcare authorities is the Hepatitis $\mathrm{C}$ virus and the disease cause by it, as most of the cases of Hepatitis $\mathrm{C}$ disease are reported when the disease is its advanced stage. The methodical study of the literature, pertaining to the prevalence of the HCV, suggests that in the non-urban regions 
of Pakistan, the HCV is endemic in Pakistan and in coming years the rate of its occurrence may increase despite the evolution of regimen that is used to cure the infection caused by the HCV Rubi G et al. [9]. For instance, as per some statistical estimates regarding the occurrence rate of Hepatitis $\mathrm{C}$ disease in urban and rural regions of Pakistan, the prevalence of HCV in the rural areas have increased around $25 \%$, which suggests that the causes such as quality of food, water and healthcare are major causes of HCV infection in an individual Umer \& Iqbal [10]. This information suggests it is essential to study HCV not only from the medical perspective but also from the socio-economic perspective.

As per statistics, retrieved from the study by Arshad and Ashfaq on the prevalence of HCV in Pakistan, the prevalence of HCV varies from province to province. For instance, the study found that the prevalence of HCV was highest in the province of Baluchistan while in the Federally Administrated Tribal Areas the prevalence of HCV is comparatively low. However, it is essential to acknowledge that the population of both federally administrated area and Baluchistan is very low in comparison to the other provinces of the country. As per statistics of this study, the prevalence rate (\%) of HCV in Baluchistan is $25.77 \%$, in Khyber Pakhtunkhwah it is $6.07 \%$, in Punjab it is $5.46 \%$, in Federally Administrated Area it is $3.37 \%$ and in Sindh it is $2.55 \%$ Arshad \& Ashfaq [11].

The study by Al Kanaani et al. [12] on the prevalence of the HCV in Pakistan inferred that the prevalence of $\mathrm{HCV}$, among the general population of Pakistan, is at $6.2 \%$. However, the prevalence of the HCV among the high-risk clinical populations is estimated to be about $34.5 \%$. The study also asserts that the prevalence of HCV, among the populations that are the intermediate-risk (clinical), is around $12.8 \%$. The most interesting statistics, which the study has quoted, is that the prevalence of HCV is around 55.9\% among the populations with the liver pertaining conditions. This suggests that most of the liver related medical complications are caused by the HCV. The study has inferred that 1 among 20 Pakistanis is affected by HCV, making it a serious health issue in Pakistan Al Kanaani \& Mahmud et al. [12].

Different studies on the prevalence of HCV in Pakistan have concluded that the HCV genotype 3a has the highest occurrence rate in Pakistan. In fact, this subtype of HCV is found in around $63 \%$ of the victims of Hepatitis C in Pakistan, which suggests that particular type conditions (economic/social/topographical) are the cause of the prevalence of HCV genotype 3a. The statistics also show that the individuals, who age between 41 and 50 years, are more vulnerable to the HCV (genotype 3-a) Saleem \& Riaz et al. $[4,13]$.

\section{Conclusion}

In Pakistan, some causes play a more active role than the others in the high occurrence rate of Hepatitis $\mathrm{C}$ disease. For instance, the reuse of the syringes and quality of water are considered primary causes of high occurrence rate hepatitis disease. However, other factors, such as blood transfusion without appropriate screening is also consider a major cause of high prevalence of HCV. We have also learned that individuals, who age between 41 and 50 years, are more vulnerable to HCV than the individuals, who belong to different age groups.

It is evident that the lack of a potent vaccine has a major contribution in the increased occurrence of hepatitis $\mathrm{C}$ cases. This is because the disease caused by the HCV produces very mild symptoms in its early stage, which makes the medical processes and procedure expensive and complex. In addition, the regimen that is used to curb/cure hepatitis C disease is also less effective if the disease is in its advanced stage. Therefore, the emphasis must be in developing a potent hepatitis $\mathrm{C}$ vaccination, which may reduce the prevalence evidently and significantly.

\section{References}

1. Rubi G, Shilu Mathew, Ishtiaq Qadri (2015) Genetic Polymorphism of IL-10 \& IL-28B gene in relapsers and non-responders of Chronic HCV Patients of the Punjab. Journal of Pharmacy and Pharmaceutical Sciences 7(12).

2. Kish T, Aziz A, Sorio M (2017) Hepatitis C in a New Era: A Review of Current Therapies. Pharmacy and Therapeutics 42(5): 316-329.

3. Kitiyakara T, Redmond S, Unwanatham N, Rattanasir S (2017) The detection of hepatocellular carcinoma (HCC) from patients' breath using canine scent detection: a proof-of-concept study. J Breath Res 11(4): 046002.

4. Riaz H, Latif MZ, Qureshi MA (2016) HCV Prevalence and its Predominant Genotypes in Sargodha Region of Pakistan. Cell 4428870.

5. Graham CS, Swan T (2015) A path to eradication of hepatitis C in lowand middle-income countries. Antiviral Res 119: 89-96.

6. WHO (2017) Pakistan tackles high rates of hepatitis from many angles.

7. Kumar T, Ahmed N, Hayat MK, Gao BX, Faisal S, et al. (2017) Prevalence and Genotypic Distribution of Hepatitis C Virus in Peshawar KPK, Pakistan. HAYATI Journal of Biosciences 24(1): 22-25.

8. Qureshi H, Mohamud BK, Alam SE, Arif A, Ahmed W (2013) Treatment of hepatitis B and $C$ through national programme-an audit. J Pak Med Assoc 63(2): 220-224.

9. Rubi G, Muhammad Aslamkhan (2017) Gene Polymorphism of Responder, Relapser and Non-Responder of Chronic Hcv Infection among Ethnic Tribes of Punjab, Pakistan. J Clin Immunol Res 1(1): 1-5.

10. Umer M, Iqbal M (2016) Hepatitis C virus prevalence and genotype distribution in Pakistan: Comprehensive review of recent data. World Journal of Gastroenterol 22(4): 1684-1700.

11. Arshad A, Ashfaq UA (2017) Epidemiology of hepatitis C infection in Pakistan: current estimate and major risk factors. Crit Rev Eukaryot Gene Expr 27(1): 63-77.

12. Al Kanaani Z, Mahmud S, Kouyoumjian SP, Abu-Raddad LJ (2018) The epidemiology of hepatitis $C$ virus in Pakistan: systematic review and meta-analyses. R Soc Open Sci 5(4): 180257.

13. Saleem S, Ali A, Khubaib B, Akram M, Fatima Z, et al. (2018) Genetic diversity of Hepatitis C Virus in Pakistan using Next Generation Sequencing. J Clin Virol 108: 26-31. 
(C) This work is licensed under Creative Commons Attribution 4.0 License

DOI: 10.19080/ARGH.2019.12.555838

\section{Your next submission with JuniperPublishers} will reach you the below assets

- Quality Editorial service

- Swift Peer Review

- Reprints availability

- E-prints Service

- Manuscript Podcast for convenient understanding

- Global attainment for your research

- Manuscript accessibility in different formats ( Pdf, E-pub, Full Text, audio)

- Unceasing customer service

Track the below URL for one-step submission https://juniperpublishers.com/online-submission.php 